\title{
PENETAPAN KURVA STANDAR SENYAWA TETRA HIDROXY ETHYL DISULPHATE (THES) DALAM PLASMA MARMUT (Cavia porcellus) MENGGUNAKAN KCKT
}

\author{
Tuti Handayani Zainal, Elly wahyudin dan Yusnita Rifai \\ Fakultas Farmasi, Universitas Hasanuddin, Makassar
}

Kata Kunci :

Tetra hydroxy ethyl disulfate, HPLC, antibiotik.

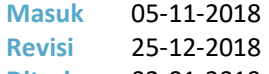

Diterima 02-01-2019

\section{Korespondensi}

\section{Elly Wahyudin}

ellywahyudins@gmail.com

Copyright

(C) 2018 Majalah Farmasi Farmakologi Fakultas

Farmasi · Makassar

Diterbitkan tanggal 02-01-2019

Dapat Diakses Daring Pada:

http://journal.unhas.ac.id /index.php/mff

\begin{abstract}
ABSTRAK
Tetra hydroxy ethyl disulphate (THES) merupakan kandidat obat baru sebagai antibiotik yang memiliki mekanisme kerja yaitu ligan sulfat yang ada pada THES akan mengikat peptidoglikan yang ada pada dinding sel bakteri menyebabkan kerusakan pada membran dinding sel bakteri. Senyawa THES ini sangat potensial untuk mengatasi resistensi antibiotik. Penelitian ini bertujuan untuk menentukan kurva regresi linier dalam plasma marmut (Cavia porcellus). Penelitian ini merupakan penelitian eksperimental yang dilakukan pada bulan Mei- September 2018. Penelitian ini menggunakan marmut jantan dengan bobot 400-600 gram. Pengambilan plasma darah marmut melalui vena cava. Pengukuran kadar THES dalam plasma marmut (Cavia porcellus) menggunakan instrumen HPLC pada panjang gelombang $254 \mathrm{~nm}$, fase gerak Asetonitril : Buffer fostat dan fase diam ODS C18 dengan laju alir 1mL/menit. Hasil penelitian menunjukkan seri konsentrasi THES dalam plasma marmut (Cavia porcellus) $10 \mathrm{mg} / \mathrm{L}, 20 \mathrm{mg} / \mathrm{L}, 30$ $\mathrm{mg} / \mathrm{L}, 40, \mathrm{mg} / \mathrm{L}$, dan $50 \mathrm{mg} / \mathrm{L}$ berturut- turut diperoleh luas area kromatogram 37878, 27582, 82582, 111490,157286 sehingga koefisien korelasi THES dalam plasma secara in vitro sebesar $r=0.91$ dengan persamaan $\mathrm{y}=3227,2 \mathrm{x}-13454$ dan diperoleh waktu retensi 2,3 menit. Hasil penelitian dapat disimpulkan bahwa konsentrasi kadar THES dalam plasma marmut (Cavia porcellus) memenuhi uji linieritas dalam matriks biologis.
\end{abstract}

\section{PENDAHULUAN}

Penyakit infeksi merupakan salah satu masalah kesehatan yang sering terjadi di masyarakat. Masalah kesehatan tersebut membutuhkan antibiotika. Sehingga antibiotika sangat sering digunakan oleh masyarakat. Penggunaan antibiotika secara irrasional ini menyebabkan banyak bakteri yang mengalami resistensi antibiotika. Pada beberapa penelitian penggunaan antibiotik di rumah sakit ditemukan persentase mencapai $80 \%$ penggunaan antibiotik tidak didasarkan pada indikasi [1]. Penggunaan antibiotik secara irrasional ini menimbulkan berbagai masalah dalam pengobatan penyakit infekssi dan kerugian secara ekonomi. Olehnya itu dibutuhkan antibiotik baru untuk mengatasi resistensi antibiotika yang ampuh dan dengan harga yang memadai [2].

Resistensi adalah kemampuan bakteri untuk menetralisir dan melemahkan daya kerja antibiotik. Resistensi dapat terjadi dengan beberapa cara, yaitu: bakteri merusak enzim yang diproduksi antibiotik; bakteri mengubah reseptor sel target antibiotik; mengubah sifat fisikokimiawi target sasaran antibiotik pada sel bakteri; perubahan sifat dinding sel bakteri yang menyebabkan antibiotik tidak dapat menembus dinding sel; melalui mekanisme transport aktif ke luar sel antibiotik dikeluarkan kembali oleh sel bakteri [3].

Tetra hydroxy ethyl disulphate (THES) merupakan obat baru yang sebagai antibiotik yang memiliki mekanisme kerja membunuh bakteri pada membran dinding sel. Senyawa hasil sintesis EDTA bekerja dengan cara merusak dinding sel bakteri dengan cara mengikat peptidoglikan yang ada pada dinding sel bakteri dengan ligan sulfat yang ada pada THES [4].

Penelitian terhadap senyawa baru ini Tetra hydroxy ethyl disulphate (THES) masih perlu dikembangkan. Sehingga dilakukan penelitian ini guna menentukan kurva regresi linier dalam plasma marmut (Cavia porcellus). Berdasarkan uraian diatas, maka akan dilakukan penentuan konsentrasi kurva standar senyawa tetra hidroxy ethyl disulphate (THES) dalam plasma marmut (cavia porcellus) menggunakan HPLC.

\section{METODE PENELITIAN}

\section{Alat dan Bahan Penelitian}

Alat-alat yang digunakan dalam penelitian ini adalah erlenmeyer, hair dryaer, kanula, labu tentukur, magnetic stirer, mikropipet 100-1000 $\mu \mathrm{l}$, spoit, timbangan analitik, tip mikropipet, tabung sentrifuge, stopwatch, ultra fast liquid chromatography (UFLC), vial autosampler, vortex.

Bahan-bahan yang digunakan dalam penelitian ini adalah aquadest, aquadest pro injeksi, asetonitril, buffer phosphate, methanol grade HPLC, tabung EDTA dan senyawa Tetra Hidroxy Ethil Di Sulphate (THES)

\section{Pemilihan Hewan Uji}

Penelitian eksperimental ini menggunakan hewan uji marmut (Cavia porcellus) jantan dengan bobot badan rata-rata 400 gram. Hewan uji diadaptasikan selama 7 hari dalam laboratorium dengan memantau pola makan, keadaan fisik dan needle, penyaring UFLC, sonikator, sentrifuse, 
aktivitas yang baik sebelum perlakuan.

\section{Pembuatan Larutan Baku}

Sebanyak 10 mg THES dilarutkan dengan aqua pro injeksi dalam labu tentukur $10 \mathrm{ml}$, kemudian dicukupkan sampai volume batas sehingga diperoleh konsentrasi larutan 1000 bpj sebagai larutan stok (5). Kemudian dibuat seri konsentrasi 10 ppm, 20 ppm, 30 ppm, 40 ppm dan 50 ppm dengan memipet dari larutan stok THES sebanyak masingmasing $100 \mu \mathrm{L}, 200 \mu \mathrm{L}, 300 \mu \mathrm{L}, 400 \mu \mathrm{L}$, dan $500 \mu \mathrm{L}$ dan dicukupkan volumenya hingga batas labu tentukur [5].

\section{Penyiapan sampel uji (analit)}

Cuplikan darah dari hewan uji marmut dimasukkan dalam tabung EDTA lalu disentrifugasi dengan kecepatan 25000 rpm selama 15 menit kemudian endapannya dipisahkan dengan cara enap tuang dan sampel plasma yang diperoleh dimasukkan kedalam freezer $20^{\circ} \mathrm{C}$ sebelum diekstraksi dan dianalisa.

\section{Pembuatan Kurva Baku}

Larutan baku yang telah dibuat, masing-masing sebanyak $100 \mu \mathrm{l}$ ditambahkan kedalam $50 \mu \mathrm{l}$ plasma dan $400 \mu \mathrm{l}$ asetonitril grade HPLC sebagai pengendap protein. Masingmasing sampel plasma divortex selama 5 menit dan disentrifus dengan kecepatan 10000 rpm selama 20 menit. Diambil $20 \mu \mathrm{L}$ masing-masing dari supernatan dan disaring menggunakan penyaring khusus UFLC dan disuntikkan sebanyak $20 \mu \mathrm{L}$ ke dalam UFLC, dengan fase diam ODS C18 dengan suhu kolom $30^{\circ} \mathrm{C}$ fase gerak berupa asetonitril : bufer fosfat dengan daya alir $1 \mathrm{~mL} /$ menit. Luas area dari komatogram sampel yang diperoleh digunakan untuk menentukan kurva baku THES dalam plasma dan urin.

\section{Interpretasi Data}

Nilai luas area yang diperoleh dari masing-masing sampel plasma kemudian diplot terhadap seri konsentrasi THES dalam bentuk kurva dengan menggunakan perangkat lunak Microsoft Excel. Berdasarkan kurva tersebut, dapat ditentukan regresi linier senyawa THES dalam plasma marmut (Cavia porcellus).

\section{HASIL DAN PEMBAHASAN}

Instrument analisis kini banyak digunakan guna memenuhi kebutuhan industri dan pengembangan obat baru. Salah satunya teknik kromatografi cair kinerja tinggi (KCKT). Prinsip kerja KCKT atau lebih dikenal HPLC (high performance liquid chromatography) adalah pemisahan komponen analit berdasarkan kepolarannya, setiap komponen senyawa yang keluar akan terdeteksi dengan detektor dan direkam dalam bentuk kromatogram. Dimana jumlah peak menyatakan jumlah komponen, sedangkan luas peak menyatakan konsentrasi komponen dalam senyawa [6].

Pada penelitian ini menggunakan KCKT fase terbalik (reverse phase column), dimana fase diam berupa silica dimodifikasi ODS 18 dan fase gerak berupa asetonitril: buffer fosfat yang sifatnya polar. Kromatografi fasa terbalik melibatkan fasa gerak polar (aqueous). Akibatnya, molekul-molekul hidrofobik cenderung teradsorpsi pada fasa diam hidrofobik, dan molekul-molekul hidrofilik dalam fasa gerak akan melewati kolom dan terelusi lebih dulu. Dengan kata lain, sampel yang masuk dalam kolom akan didorong oleh fase gerak sehingga senyawa yang terkandung dalam sampel akan dianalisis. Senyawa non polar dalam sampel akan lebih lama melewati kolom. Sementara senyawa polar akan melewati kolom lebih cepat. Perbedaan tingkat kepolaran ini mengakibatkan waktu retensi berbeda pada senyawa polar dan senyawa kurang polar. Pemilihan fase gerak sangat berpengaruh terhadap senyawa-senyawa yang ada dalam sampel. Optimasi perbandingan fase gerak asetonitril : buffer fosfat adalah 7:3 dengan panjang gelombang $254 \mathrm{~nm}$ diperoleh waktu retensi THES 2,3 menit.

Nilai korelasi merupakan nilai yang mennunjukkan kekuatan dan arah hubungan linier yang dilambangkan dengan nilai " $r$ ". Semakin nilai $r$ mendekati 1, maka kedekatan sampel uji semakin bagus. Luas area dari kromatogram analit dihubungkan dengan seri konsentrasi THES dalam plasma dalam bentuk kurva. Nilai regresi linier THES dalam plasma adalah 0.91, nilai ini menunjukkan linearitas semakin mendekati 1 dinyatakan memenuhi kriteria uji linearitas.

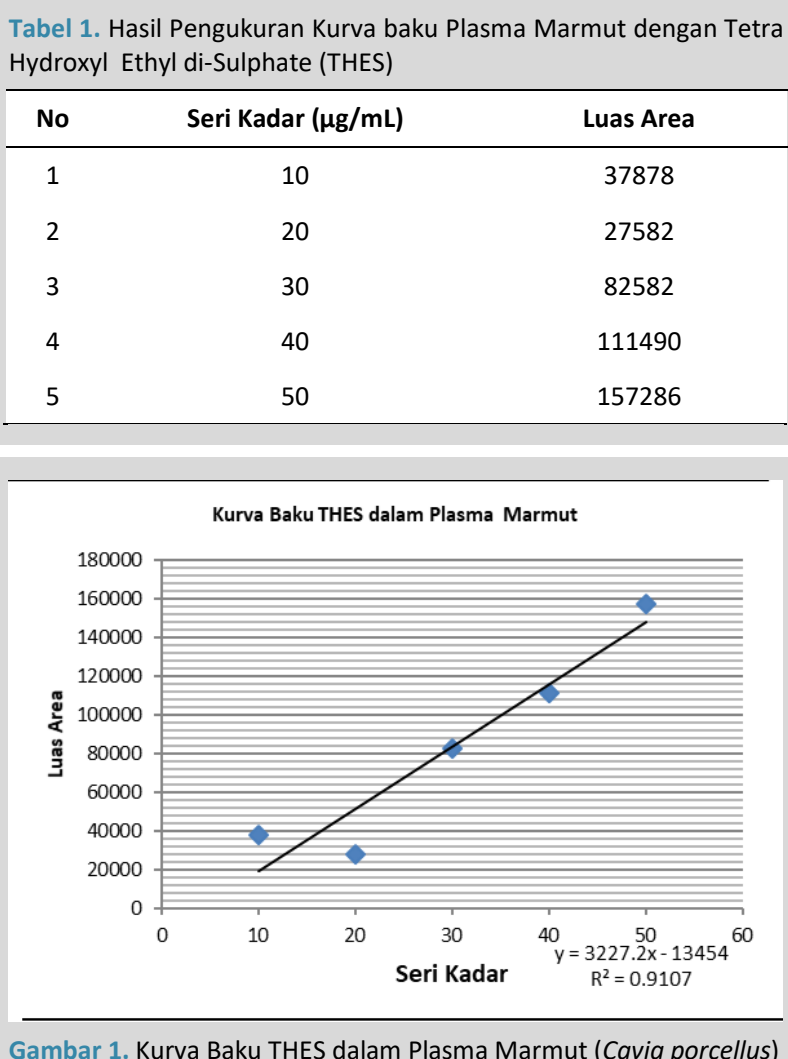

\section{KESIMPULAN}

Koefisien korelasi kurva baku THES dalam plasma sebesar $\mathrm{r}=$ 0.91 dengan persamaan $\mathrm{y}=33227,2 \mathrm{x}-13454$ dapat disimpulkan bahwa kadar THES sebagai kurva standar THES dalam plasma marmut (Cavia porcellus) memenuhi uji linieritas dalam matriks biologis.

\section{UCAPAN TERIMA KASIH}

Terima kasih yang sebesar-besarnya dan penghargaan setinggi-tingginya kepada pembimbing Ibu Prof. Elly Wahyudin, DEA, Apt. dan Ibu Yusnita Rifai, S. Si., M.Pharm., PhD., Apt. Terima kasih pula kepada keluraga tercinta dan semua pihak atas do'a, dukungan dan segala bentuk bantuan kepada penulis.

\section{DAFTAR PUSTAKA}

1. Hadi U, Duerink, D.o.,Lestari, dkk. 2009. Audit Of Antibiotic Prescribing in Two Govermental Teaching Hospital in Indonesia. Clinical Microbiology and Infection.

2. Sri Mulyani. 2013. Kimia dan Bioteknologi Dalam Resistensi Antibiotik. Program Studi Kimia Jurusan FMIPA. Surakarta

3. Karl Drlica, David S. Perlin. 2011. Antibiotic Resistance: Understanding and Responding to an Emerging Crisis. Emergency Infectious Disease. NCBI

4. Haryono, wardoyo, 2015. Tetra Hidroxy Ethyl di-Sulfate Nitricide,Tanggerang

5. Muhammad Tang. 2017. Skripsi : Validasi Metode Analisis Penetuan kadar Senyawa Tetra Hydorxy Ethyl Disulphate (THES) Menggunakan Metode UFLC. Farmasi Unhas, Makassar 
